Original Research Paper

\title{
Comparative Profitability Analysis and Policy Options for Sustaining Integrated Pest Management Practices on Cucumber (Cucumis sativus L.) Production
}

\author{
Kaynath Akhi and Shamima Islam \\ Department of Agricultural Economics, Bangabandhu Sheikh Mujibur Rahman Agricultural University, Bangladesh
}

\author{
Article history \\ Received: 03-11-2019 \\ Revised: 02-03-2020 \\ Accepted: 06-03-2020 \\ Corresponding Author: \\ Kaynath Akhi \\ Department of Agricultural \\ Economics, Bangabandhu \\ Sheikh Mujibur Rahman \\ Agricultural University, \\ Bangladesh \\ Email: kaynathakhi@bsmrau.edu.bd
}

\begin{abstract}
This study examined the comparative profitability of cucumber (Cucumis sativus L.) production between Integrated Pest Management (IPM) and non-Integrated Pest Management (non-IPM) farmers and tried to find out the policy recommendations for sustaining this practice in vegetable production. A total of 80 farmers (40 from each group) were purposively selected from Tangail district of Bangladesh through the interview schedule. To fulfill the objectives of this study, farmers' attitude index, profitability and partial budget analysis were used. Hence, to know the complete picture of cucumber production using both IPM and non-IPM technology, the socioeconomic profile of farmers was examined and compared and found that IPM farmers were in betteroff condition than that of non-IPM farmers. The result of the farmers' attitude measured by Likert Scale showed that the majority of the farmers had a moderately favorable attitude towards IPM technology. According to the profitability analysis, the benefit-cost ratio of cucumber production was 1.9 for IPM farmers, while for non-IPM farmers, it was estimated at 1.6. It is evident from the partial budget analysis that per hectare net benefit was USD 1069.23 for cucumber production using IPM technology. Cucumber production was profitable for both IPM and non-IPM farmers, but IPM farmers were more beneficial than that of non-IPM. The researcher identified a weak socioeconomic profile of the farmers, inadequate training facilities, few NGOs participation and poor IPM disseminating staff and farmers' ratio as the challenges of sustaining IPM technology in the study areas. Therefore, government attention needs to be increased on collaboration between different groups, including national and international organizations, social scientists and farmers for sustaining IPM practices.
\end{abstract}

Keywords: Attitude Index, Benefit-Cost Ratio, Partial Budget, Sustainability

\section{Introduction}

The demand for safe organic food has been growing significantly all over the world for the past several years due to increasing consumer awareness of health and environmental issues and this offers producers and exporters in developing countries opportunities to improve their incomes and living conditions (FiBL, 2006). To ensure food for the large population, the 'green revolution' appeared in the1960s with the concept of 'producing more food' and within a short period, it was implemented in Bangladesh like other Asian countries (Hoque, 2012). With the introduction of the green revolution High Yielding Varieties (HYV), chemical fertilizers, pesticides and groundwater irrigation were also introduced and farmers started to use chemical fertilizers to meet the demand for food for an increasing population (Hossain, 2001). But the indiscriminate uses of chemical inputs have been considered as the foremost reason for stagnating or declining crop productivity, loss of biodiversity and have threatened the sustainability of agriculture. Since the 
1990s, the issue of sustainability became an important concern in agriculture due to yield stagnant and many other adverse effects (Hoque, 2012). Therefore, the emphasis is now focused on the use of organic and other byproducts of agriculture and industries (Mishra, 2005). But unfortunately, Bangladeshi farmers could not get their share from the global organic market and even failed to create an excellent domestic market of organic produces and developing the sustainability of the agricultural systems through adoption of organic agriculture due to lack of proper knowledge on organic cultivation methods (Sarker and Itohara, 2007). On the one hand, the farmers are bound to increase their yield to meet the demand of the ever-growing population; on the other hand, they should keep the soil and environment safe and sound. In this dilemma, sustainable agriculture is the one and only solution. Under the broad policy of sustainable agricultural development, the government of Bangladesh with an alliance of the Food and Agricultural Organization (FAO) has been trying to implement Integrated Pest Management (IPM) farming since 1981 (Kabir and Rainis, 2014). According to the Food and Agricultural Organization (FAO) Integrated Pest Management is: "A pest management system that, in the context of the associated environment and the population dynamics of the pest species, utilizes all suitable techniques and methods in as compatible a manner as possible and maintains the pest populations at levels below those causing economic injury."

Agriculture remains the most crucial sector of the Bangladeshi economy, contributing more than $15 \%$ percent to the national GDP and providing employment for $43 \%$ percent of the population (BBS, 2018). Vegetables are considered as an essential part of agriculture and can be identified as a significant one for this economy for its noteworthy contribution in raising the foreign exchange earnings. In addition, vegetables are generally labor-intensive crops and thus offer a considerable promise for generating rural employment opportunities, especially for unemployed women of Bangladesh. This farming is pesticide-intensive but pesticide exposure is becoming a problem as many countries growing public objections to the use of chemical pesticides because of their negative impact on human health and the environment. In this situation, IPM practices such as pheromone trap, biological control, soil solarization, soil amendments, grafting, botanicals and manual cleaning etc. can be used in vegetable cultivation (Akter et al., 2016). Among the vegetables of the Cucurbitaceae family having 118 genera and 825 species, cucumber (Cucumis sativus L.) is a popular vegetable (Khan et al., 2015; Maurya et al., 2015). Its local name is Khira which is a real versatile vegetable because of variety in the use from salad to pickles as well as from digestive aids to beauty products (Maurya et al., 2015). A fresh cucumber provides vitamin $C$, niacin, iron, calcium, thiamine, fibers and phosphorus (Khan et al., 2015; Sanjeev et al., 2015). More than 50\% production of cucumber comes from Asia and Turkey; Iran, Uzbekistan, Japan and Iraq were considered as leading cucumber producing countries in Asia (Khan et al., 2015). But a significant amount of production is lost every year due to relentless attacks by various pests. The cucurbit fruit fly is a highly damaging pest of almost all the cucurbit vegetables (Nasiruddin et al., 2015). In the study area the majority of the cucumber growers' gradually adopting IPM methods for pest control, especially for fruit fly. Farming systems based on Integrated Pest Management (IPM) technologies can reduce the use of pesticides to a great extent without causing harm to the yield (Kabir and Rainis, 2014). IPM technology promises higher returns or lower costs to the cucumber growers (Akter et al., 2016).

Kamal et al. (2018) did a study to determine the adoption of Integrated Pest Management (IPM) practices by the vegetable growers and to explore the relationships between the adoptions of IPM practices in vegetable cultivation. Akter et al. (2016) compare the profitability analysis of IPM and non-IPM technology on vegetable cultivation, which stated that IPM based cultivation, was more profitable than that of non-IPM based cultivation. Islam et al. (2017a) performed research on an economic study on practicing IPM technology for producing bitter gourd in selected areas of the Comilla district and the study revealed that IPM farmers gained more profit than non-IPM farmers on bitter gourd production. McCarthy et al. (2015) evaluate the effectiveness and impacts of USAID's IPM IL vegetable technology transfer subproject in Bangladesh. However, most of the researches (Rahman and Noerton, 2019; Islam et al., 2017b, Kabir, 2015; Kabir and Rainis, 2014) were conducted on the adoption of IPM practices by vegetable growers and very little is known about the economic benefit of using IPM technologies for vegetable cultivation. There was no exclusive study on the profitability of cucumber cultivation by using IPM technology especially for the farmer with a poor socioeconomic background of any developing country like Bangladesh. For this reason, the present study attempts to determine the profitability of IPM based cucumber production and compare with that of the conventional cucumber production as well as to provide some policy implications for sustaining IPM practices in vegetable production. In a word, this study is a modest attempt to find a way of sustainability in vegetable production as well as agriculture. 


\section{Materials and Methods}

\section{Selection of the Study Area}

Considering the intensity of using IPM technology in cucumber production two villages of Ganya union under Tangail Sadar Upazila of Tangail district of Bangladesh were purposively selected. In selecting the study area, necessary help was taken from the Department of Agricultural Extension (DAE).

\section{Sample Size and Sampling Technique}

A total of 80 respondents (40 IPM and 40 nonIPM) were interviewed from Tangail district through interview schedule by the researchers during March to April 2018.

\section{Analytical Techniques}

Descriptive statistics along with the following analytical techniques were used to achieve the objectives of the study.

\section{Farmers' Attitude Towards IPM Technology}

Farmers' attitude towards IPM technology was the focus variable of the study. For measuring the attitude of the respondents, a 5-point Likert Scale was used. There were 15 statements including both favor and disfavor against the 5-point scale. All the statements were arranged randomly to avoid subjects' bias in expressing their opinion. Each respondent was asked to indicate his/her attitude against each statement along a 5-point scale, i.e., 'strongly agree', 'agree', 'no opinion', 'disagree' and 'strongly disagree'. Weights assigned to these responses were 4, 3,2, 1 and 0 in favor and $0,1,2$, 3 and 4 in disfavor. The total score of a respondent was determined by summing up the weights for responses against all the 15 statements. Attitude score for each statement was calculated by using Attitude Index (AI) and it was calculated by using the following formula (Islam et al., 2017a):

$$
\begin{aligned}
& \text { Attitude Index }(A I)=4 \times S A+3 \times A+2 \\
& \times N O+1 \times D A+0 \times S D A(\text { in favor })
\end{aligned}
$$

Or:

Attitude Index $(A I)=0 \times S A+1 \times A+2$

$\times N O+3 \times D A+4 \times S D A$ (in disfavor

Where:

$S A=$ Total number of respondents expressing their attitude 'strongly agree' for the statement

$A=$ Total number of respondents expressing their attitude 'agree' for the statement

$N O=$ Total number of respondents expressing their attitude 'no opinion' for the statement

DA $=$ Total number of respondents expressing their attitude 'disagree' for the statement

$S D A=$ Total number of respondents expressing their attitude 'strongly disagree' for the statement

\section{The Profitability of cucumber production}

The profitability of cucumber production was measured per hectare by using gross return, gross margin, net return and benefit-cost ratio (undiscounted). The formulas used for the calculation of profitability are:

- Gross return, $\mathrm{GR}=\mathrm{P} \times \mathrm{Q}$; where, $\mathrm{P}=$ Selling price of the product (USD); $\mathrm{Q}=$ Yield per hectare $(\mathrm{Kg})$

- Gross cost, GC = TFC + TVC; where TFC $=$ Total fixed cost (USD); and TVC $=$ Total variable cost (USD)

- Gross margin, $\mathrm{GM}=\mathrm{GR}-\mathrm{TVC}$

- $\quad$ Net return, NR $=$ GR - GC

- Benefit-cost ratio $=$ Gross benefit $/$ Gross cost

\section{Partial budget analysis}

Partial budget analysis is the tabulation of expected gains and losses due to a relative change (marginal) in farming methods or technology. In the present study, a partial budget framework was used to analyze the effect of using IPM technology for producing cucumber. Table 1 shows the partial budget format that facilitates the analysis and comparison of alternatives.

\begin{tabular}{|c|c|c|c|}
\hline \multicolumn{2}{|l|}{ Positive impacts } & \multicolumn{2}{|l|}{ Negative impacts } \\
\hline Items & Unit of analysis & Items & Unit of analysis \\
\hline a. Additional returns & & a. Additional costs & \\
\hline b. Reduced costs & & b. Reduced returns & \\
\hline A. Total positive impacts & & B. Total negative impacts & \\
\hline Net benefit $=(A-B)$ & & & \\
\hline
\end{tabular}

Table 1: Partial budget format

Source: Roth et al. (2002) 


\section{Results and Discussion}

\section{Socioeconomic Characteristics of the Sample Farmers}

The study identified that most of the IPM farmers were in young $(42.5 \%)$ and middle $(35.0 \%)$ age group while that of the non-IPM farmers were in middle (40.0\%) and old (37.5\%) aged group. Akter et al. (2016) and Kamal et al. (2018) also found almost similar findings. Elderly farmers seem to be somewhat less motivated to adopt IPM practices than younger and a middle aged farmers. Young and middle aged people generally show a more favorable attitude towards trying IPM practices. In the case of IPM farmers, $42.5 \%$ and $32.5 \%$ of the respondents had primary and secondary levels of education respectively and only a small $17.5 \%$ and $7.5 \%$ of the respondents were illiterate and having higher secondary and above education respectively. On the other hand, the percentage of illiterate (27.5\%) farmers was comparatively high in non-IPM farmers as well as no non-IPM farmers completed their higher secondary education which indicates that educated people are more innovative and more conscious about sustainable agriculture. The average family size was found 4.84 for IPM farmers and 5.16 for non-IPM farmers of the study area which is more than that of national average 4.060 (HIES, 2016). The average farm size of IPM farmers $(0.57 \mathrm{ha})$ was more than that of non-IPM farmers ( 0.35 ha) and this result match the findings of Akter et al. (2016). The annual income and income from the cucumber cultivation of IPM farmers was higher than that of non-IPM farmers. The majority of the respondents had low (45\%) and medium $(22.5 \%)$ training exposure and $22.5 \%$ had no training exposure while only a few $(10 \%)$ had high training exposure in the case of IPM farmers. On the other hand, $50 \%$ of non-
IPM farmers had no training experience in the study area. Kamal et al. (2018) also found almost similar findings. Based on the descriptive evidence from this study, it was noticed that there were some variations in socioeconomic characteristics of IPM and non-IPM cucumber producers (Table 2). The results indicate that the IPM practicing farmers were in better-off condition than that of non-IPM farmers in all socioeconomic characteristics.

\section{Measurement of Farmers' Attitude Towards IPM Technology}

Farmers' attitude towards IPM technology was investigated in this research. The extent of the opinion of the farmers against 15 statements was assessed in this regard. The attitude score for each statement was calculated by using the Attitude Index (AI). The AI for each statement has been arranged in rank order according to their extent of opinion which appears in Table 3. Attitude Index was found to vary from 205 to 278 for all farmers.

Table 3 revealed the attitude index and ranking of the statements based on the attitude index. Farmers ranked nine statements positively, which scored 278 in favor. Table 3 also shows that 'training is necessary to get a clear knowledge about practicing IPM technology' got the $1^{\text {st }}$ rank among the statements. 'IPM reduces the cost of production' secured the $2^{\text {nd }}$ rank with the total AI 251 whereas, 'IPM is a good and effective method' attained the 3rd rank with the total AI 250. Most of the farmers did not agree with the statement 'IPM is a costly method' obtained $4^{\text {th }}$ rank with the total AI 249 in disfavor situation. However, the majority of the farmers (including both IPM and Non- IPM farmers) had a moderately favorable attitude towards IPM technology which supports the findings of Islam et al. (2017a).

Table 2: Socioeconomic characteristics of the sample farmers

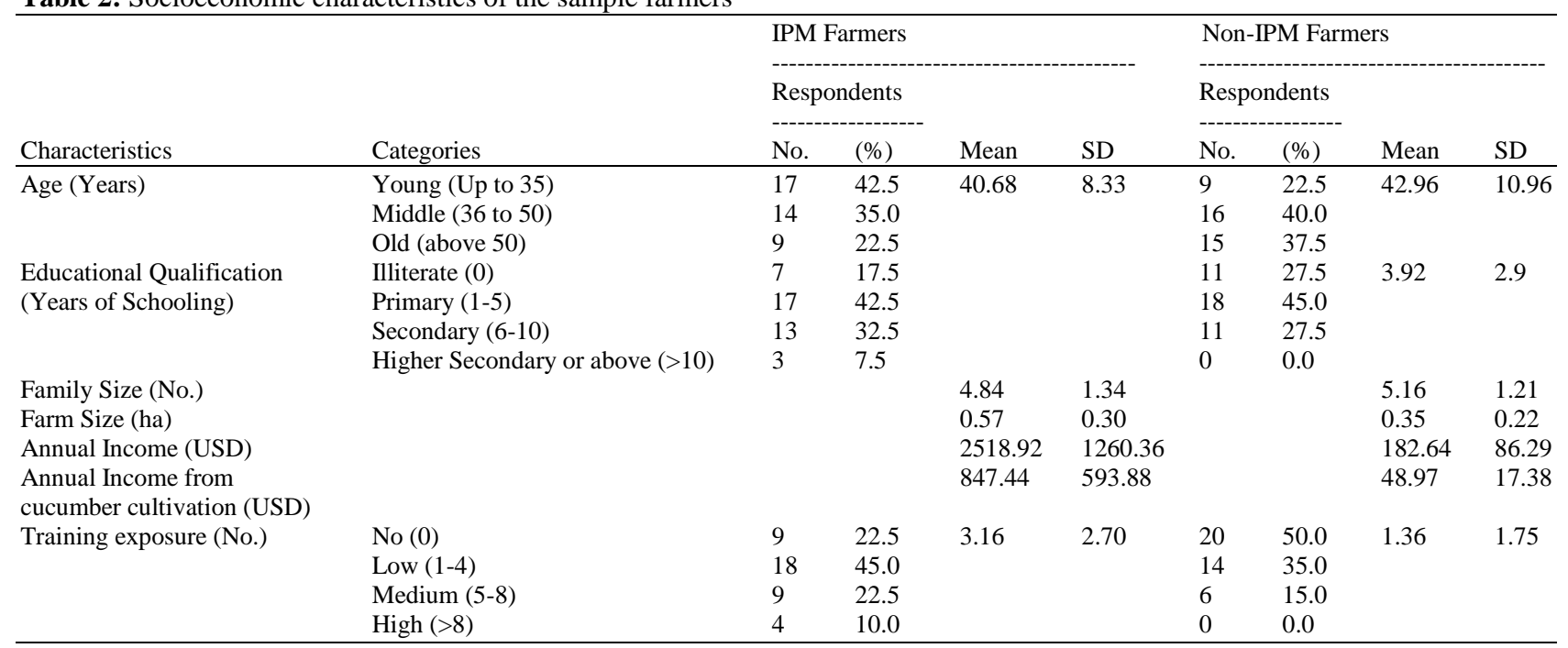


Table 3: Farmers' attitude towards IPM technology (statement-wise attitude score of the farmers)

\begin{tabular}{|c|c|c|c|c|c|c|c|c|}
\hline \multirow[b]{2}{*}{ Sl. No. } & \multirow[b]{2}{*}{ Statements } & \multicolumn{5}{|c|}{ Extent of opinion } & \multirow[b]{2}{*}{$\mathrm{AI}$} & \multirow{2}{*}{$\begin{array}{l}\text { Rank } \\
\text { order }\end{array}$} \\
\hline & & SA & A & NO & DA & SDA & & \\
\hline$\overline{1}$ & IPM is a good and effective method & 33 & 24 & 23 & 0 & 0 & 250 & 3 \\
\hline 2 & IPM has no harmful effect on the users & 28 & 14 & 38 & 0 & 0 & 230 & 9 \\
\hline 3 & IPM is environmental friendly & 23 & 15 & 42 & 0 & 0 & 221 & 12 \\
\hline 4 & $\begin{array}{l}\text { Use of insecticides is more harmful for environment than } \\
\text { better yield of vegetables }\end{array}$ & 26 & 15 & 31 & 0 & 0 & 219 & 14 \\
\hline 5 & IPM is a costly method (-) & 0 & 0 & 31 & 9 & 40 & 249 & 4 \\
\hline 6 & Pesticide use is the only way to control pests (-) & 0 & 16 & 20 & 8 & 36 & 224 & 11 \\
\hline 7 & Fruit fly can be controlled by pheromone trap & 28 & 16 & 36 & 0 & 0 & 232 & 8 \\
\hline 8 & IPM reduces the dependency on insecticides & 36 & 13 & 31 & 0 & 0 & 245 & 5 \\
\hline 9 & It is needed to use insecticides just after pest attack (-) & 0 & 3 & 32 & 12 & 33 & 235 & 7 \\
\hline 10 & $\begin{array}{l}\text { Training is necessary to get clear knowledge about } \\
\text { practicing IPM technology }\end{array}$ & 38 & 42 & 0 & 0 & 0 & 278 & 1 \\
\hline 11 & IPM is a complex method (-) & 0 & 9 & 31 & 11 & 29 & 220 & 13 \\
\hline 12 & IPM does not prevent the side effects of insecticides (-) & 0 & 0 & 48 & 19 & 13 & 205 & 15 \\
\hline 13 & IPM reduces the cost of production & 40 & 11 & 29 & 0 & 0 & 251 & 2 \\
\hline 14 & Using IPM practices increase vegetable quality & 36 & 7 & 37 & 0 & 0 & 239 & 6 \\
\hline 15 & IPM does not prevent the indiscriminate use of pesticides (-) & 0 & 2 & 38 & 13 & 27 & 225 & 10 \\
\hline
\end{tabular}

Note: (-) = Disfavor situation

\section{Profitability of Cucumber Production}

\section{Estimation of Different Costs for both IPM and Non-IPM Cucumber Farmers}

Per hectare cost of human labor for sowing/planting is very high in Tangail sadar upazila. Cucumber farmers hired labor during the planting period. They also hired workers for weeding, harvesting, digging, assembling etc. purposes. Table 4 shows that in the case of IPM farmers, the human labor costs of cucumber cultivation were USD 1033.91, while for non-IPM farmers, the costs was USD 1112.96. It was revealed from the table that human labor cost is the foremost cost item for both IPM and non-IPM farmers. Islam et al. (2017b) and Akter et al. (2016) also found almost the same findings. The average power tiller cost was estimated USD 73.53 for both IPM and non-IPM farmers for this study area. The average seeds/ seedlings cost and cow dung and oilcake cost of cucumber was higher in IPM farmers than non-IPM farmers. As the farm size was estimated larger for IPM farmers and they were interested to use organic fertilizer. On the contrary inorganic fertilizers (i.e., Urea, TSP, MoP) cost were estimated higher for non-IPM farmers. Only IPM farmers used pheromone trap and the cost of pheromone trap was USD 105.51 for per hectare production of cucumber which constitutes $4.3 \%$ of the total cost of production. The average insecticides cost was nearly 2 times more for non-IPM farmers. The land use cost was the same for both IPM and non-IPM farmers. Land used cost varied from the union to union depending upon the soil type, topography, location and security of the particular crop field. The lease value of land in the study area was considered as land use cost for the present study. Per hectare total costs of cucumber production were USD 2461.27 for IPM farmers and USD 2622.44 for non-IPM farmers. It is clear from Table 4 that the cost of non-IPM farmers was higher than that of IPM farmers in the study area. Islam et al. (2017b) and Akter et al. (2016) also found almost the same findings.

IPM farmers receive more gross returns and gross margins than non-IPM farmers (Table 4). In case of IPM farmers' net return was estimated at USD 2453.72 and USD 1451.47 for non-IPM farmers. Moreover, per hectare benefit-cost ratio of IPM farmers for producing cucumber was 1.9 while in case of non-IPM farmers it was estimated 1.6, which indicates that though both of the groups are in profitable condition but IPM farmers are more profitable than non-IPM farmers. This finding also matches the findings of Islam et al. (2017b) and Akter et al. (2016).

Based on the above results and discussions, it can be concluded that the production of cucumber was profitable for both IPM and non-IPM farmers. However, IPM based farming was more profitable than that of nonIPM based farming. That indicates that there is a vast scope to increase the production of cucumber as well as vegetables by using the existing IPM practices.

\section{Partial Budget Analysis}

Table 5 indicates that per hectare additional return of using IPM technology was USD 841.09 for cucumber production. This may be due to increasing the quantity of cucumber. The operating costs that can be reduced if farmers using IPM technology were: Cost of labor, seed or seedlings cost, fertilizer cost, insecticides and trellis making were estimated at USD 79.04, 37.34, 158.87, 87.77 and 6.30, respectively and per hectare total costs reduced by using IPM technology was USD 369.33 for cucumber production (Table 5). 
Table 4: Per hectare production cost and return of cucumber for both IPM and non-IPM farmers (USD)

\begin{tabular}{lll}
\hline Particulars & IPM Farmers & Non-IPM Farmers \\
\hline Labor & $1033.91(42.0)$ & $1112.96(42.4)$ \\
Seed & $114.45(4.6)$ & $77.10(2.9)$ \\
Power tiller cost & $73.53(2.98)$ & $73.53(2.8)$ \\
Organic fertilizer & $131.50(5.3)$ & $95.82(3.7)$ \\
Cow dung & $91.71(3.7)$ & $65.45(2.5)$ \\
Oilcake & $39.79(1.6)$ & $30.37(1.2)$ \\
Inorganic fertilizer & $225.42(9.1)$ & $384.29(14.7)$ \\
Urea & $89.46(3.6)$ & $174.40(6.7)$ \\
TSP & $93.40(3.8)$ & $136.84(5.2)$ \\
MoP & $42.55(1.7)$ & $73.05(2.8)$ \\
Pheromone trap & $105.51(4.3)$ & 0.00 \\
Insecticide & $93.36(3.8)$ & $181.13(6.9)(5.1)$ \\
Trellis making & $128.20(5.2)$ & $134.50(5.1)$ \\
Irrigation & $133.91(5.4)$ & $137.69(5.3)$ \\
Total Variable cost & $2039.77(82.8)$ & $2197.01(83.8)$ \\
Interest on operating capital & $50.99(2.1)$ & $54.93(2.1)$ \\
Land use cost & $370.50(15.1)$ & $370.50(4.1)$ \\
Total Fixed cost & 421.49 & 425.43 \\
Total cost & 2461.27 & 2622.44 \\
Gross Return & 4914.99 & 4073.90 \\
Gross Margin & 2875.22 & 1876.89 \\
Net Return & 2453.72 & 1451.47 \\
BCR & 1.9 & 1.6
\end{tabular}

N.B.: Values in parenthesis indicate the percentage of total cost

Table 5: Partial budget analysis of using IPM technology for producing cucumber

\begin{tabular}{|c|c|c|c|}
\hline \multicolumn{2}{|l|}{ Positive impacts } & \multicolumn{2}{|l|}{ Negative impacts } \\
\hline Items & (USD/Hectare) & Items & (USD/Hectare) \\
\hline a. Additional return & 841.09 & $\begin{array}{l}\text { a. Additional costs } \\
\text { Organic fertilizer } \\
\text { Pheromone trap } \\
\text { Total additional costs }\end{array}$ & $\begin{array}{l}35.68 \\
105.51 \\
141.19\end{array}$ \\
\hline $\begin{array}{l}\text { b. Reduced costs } \\
\text { Labor } \\
\text { Seedling } \\
\text { Inorganic fertilizer } \\
\text { Insecticide } \\
\text { Trellis making }\end{array}$ & $\begin{array}{l}79.04 \\
37.34 \\
158.87 \\
87.77 \\
6.3\end{array}$ & b. Reduced return & 0 \\
\hline $\begin{array}{l}\text { Total reduced costs } \\
\text { A. Total positive impacts } \\
\text { Net benefit }=(A-B)=1069.23\end{array}$ & $\begin{array}{l}369.33 \\
1210.42\end{array}$ & B. Total negative impacts & 141.19 \\
\hline
\end{tabular}

The primary added expenses that IPM farmers may incur by using IPM technology were the cost of organic fertilizer and pheromone trap cost estimated to be USD 35.68 and 105.51 respectively (Table 5). Therefore, per hectare total additional cost of using IPM technology was USD 141.51 for cucumber production. Finally, it was revealed that per hectare net benefit is positive and estimated at USD 1069.23 for cucumber production by using IPM technology. It is evident from this analysis that IPM technology using is profitable and IPM farmers are more profit earners than non-IPM farmers. So, farmers should use IPM technology to produce cucumber.

\section{Conclusions and Policy Recommendation}

Based on the descriptive evidence, it was noticed that there were some variations between IPM and non-IPM farmers groups in terms of socioeconomic characteristics where the IPM practicing farmers were in better-off condition than that of non-IPM farmers. It was found that the majority of the farmers (including both IPM and non- IPM farmers) had a moderately favorable attitude towards IPM technology by using attitude index (AI). In case of IPM farmers, per hectare benefit-cost ratio of cucumber production was 1.9 while for non-IPM farmers it was estimated 1.6. It is evident from the partial budget 
analysis that per hectare net benefit was positive and determined to be USD 1069.23 for cucumber production by using IPM practices. Hence, it can be concluded that cucumber production was profitable for both IPM and non-IPM farmers in the study area but IPM based cultivation was more profitable than that of the traditional or conventional production system. But, the researcher identified the poor socioeconomic profile of the farmers, inadequate training facilities, few NGOs participation and poor IPM disseminating staff and farmers' ratio as the challenges of sustaining IPM practices in the study area. Therefore, the government can make an annual budget allocation for IPM activities and place the fund with the National IPM Program. As a result, more farmers could be interested in adopting IPM practices in the future. Besides, the extension services need to be strengthened to increase coordination between farmers and extension workers. Consequently, the government needs to be increased more attention to the collaboration between different groups, including national and international organizations, social scientists and farmers for sustaining IPM technology.

\section{Acknowledgment}

The authors express their earnest gratitude to the respondents and stakeholders of the study areas for their cooperation in conducting surveys and collecting the data and information.

\section{Author's Contributions}

Kaynath Akhi: Participated in research design, data collection, data analysis, manuscript preparation.

Shamima Islam: Participated in data collection, data analysis, manuscript preparation and review.

\section{Conflict of Interest}

The authors declare that they have no conflict of interest.

\section{References}

Akter, M., M.N. Islam, H. Afrin, S.A. Shammi and F. Begum et al., 2016. Comparative profitability analysis of IPM and non-IPM technology on vegetable cultivation in selected areas of Kishoreganj District in Bangladesh. Progressive Agric., 27: 311-319. DOI: 10.3329/pa.v27i3.30812

BBS, 2018. Bangladesh 45 years agriculture statistics of major crops (Aus, Amon, Boro, Jute, Potato and Wheat). Bangladesh Bureau of Statistics, Statistical Division, Ministry of Planning, People's Republic of Bangladesh.
FiBL, 2006. The world of organic agriculture, statistics and emerging trends.

HIES, 2016. Household income and expenditure survey HIES. Bangladesh Bureau of Statistics. Statistical Division, Ministry of Planning, People's Republic of Bangladesh.

Hoque, M.N., 2012. Eco-friendly and organic farming in Bangladesh- International classification and local practice. Ph.D. Thesis, Justus Liebig University, Giessen, Germany.

Hossain, M.Z., 2001. Farmers's view on soil organic matter depletion and its management in Bangladesh. Nutrient Cycl. Agroecosyst., 61: 197-204. DOI: 10.1007/978-94-017-2172-1_18

Islam, S., D.M.S. Islam and R. Khanum, 2017a. Economic impact of practicing IPM technology on bitter gourd (Momordicacharantia L.) production in Comilla District of Bangladesh. Agriculturists, 15: 11-23. DOI: 10.3329/agric.v15i2.35460

Islam, S., D.M.S. Islam and R. Khanum, 2017b. Adoption of IPM technology on bitter gourd production in Comilla district of Bangladesh. Bangladesh J. Political Economy, 31: 225-238.

Kabir, M.M., 2015. Adoption of Integrated Pest Management (IPM) practices in rice cultivation by the farmers of Shahjadpur upazilla under Sirajganj district. Department of Agricultural Extension and Information System, Sher-e-Bangla Agricultural University, Sher-e-bangla Nagar, Dhaka-1207.

Kabir, M.H. and R. Rainis, 2014. Adoption and intensity of Integrated Pest Management (IPM) vegetable farming in Bangladesh: An approach to sustainable agricultural development. Environ. Dev. Sustainability, 17: 1413-1429. DOI: $10.1007 / \mathrm{s} 10668-014-9613-y$

Kamal, M.M., K.M.N. Saleheen, M.S. Islam and M.B. Ahmed, 2018. Adoption of Integrated Pest Management (IPM) practices by the vegetable growers at sadar upazila under Jhenaidah district. J. Bangladesh Agril Univ, 16: 366-371.

DOI: 10.3329/jbau.v16i3.39394

Khan, Z., A.H. Shah, R. Gul, A. Majid and U. Khan et al., 2015. Morpho-agronomic characterization of cucumber germplasm for yield and yield associated traits. Int. J. Agronomy Agric. Res., 6: 1-6.

Maurya, G.P., V. Pal, G.P. Singh and L.K. Meena, 2015. An economic analysis of cucumber cultivation in Sultanpur district of Uttar Pradesh (India). Int. J. Agric. Sci. Res., 5: 23-28.

McCarthy, E.T., 2015. Analyzing the impacts of an IPM vegetable technology transfer in Bangladesh. M.S. Thesis, Agriculture and Applied Economics, Virginia Polytechnic Institute and State University, USA. 
Mishra, B.B., 2005. Sustainable agriculture for food security. Orissa Review.

Nasiruddin, M., S.N. Alam, M. Khorsheduzzaman, H.S. Jasmine and A.N.M.R. Karim et al., 2015. Article on management of cucurbit fruit fly, Bactrocera Cucurbitae, in bitter gourd by using pheromone and indigenous bait traps and its effect on year-round incidence of fruit fly. BARI, Joydebpur, Gazipur, Bangladesh.

Rahman, M.S. and G.W. Noertonb, 2019. Adoption and impacts of integrated pest management in Bangladesh: Evidence from smallholder bitter gourd growers. Horticulture, 5: 32-32.

DOI: $10.3390 /$ horticulturae 5020032
Roth, S., D. Allience and J. Hyde, 2002. Partial budgeting for agricultural business. College of Agricultural Sciences, Pennsylvania State University, University Park, PA, United States.

Sarker, M.A. and Y. Itohara, 2007. Information sources used by the farmers regarding practice of organic farming- a study from Bangladesh. J. Rural Probl., 37: 234-239. DOI: 10.7310/arfe1965.43.234

Sanjeev, K., N.B. Patel, S.N. Saravaiya and K.D. Desai, 2015. Economic viability of cucumber cultivation under NVPH. African J. Agric. Res., 10: 742-747. DOI: 10.5897/AJAR2014.9407 